\title{
The Process of Prescribing "Due Process"
}

\section{Frank C. Nereman*}

$\mathrm{R}^{\text {ECENTLx }}$ we were told that the dueness of government procedure is $\mathrm{R}$ not tested by "doctrinaire conception" or "loose generalities or sentiments abstractly appealing." Instead, "Whether the scheme satisfies those strivings for justice which due process guarantees, must be judged in the light of reason drawn from the considerations of fairness that reflect our traditions of legal and political thought, duly related to the public interest Congress sought to meet . . . as against the hazards or hardship to the individual that the ... [attacked] procedure would entail."

That is quite a mouthful. And no sooner were the words pronounced than a dissenting Justice retorted, "When we turn to the cases, personal preference, not reason, seems, however, to be controlling." Further, "Due process under the prevailing doctrine is what the judges say it is; and it differs from judge to judge, from court to court. ... [It is] a tool of activitists who respond to their own visceral reactions in deciding what is fair, decent, or reasonable."'2

Sanford Kadish has dissected the viewpoints those excerpts reflect, ${ }^{3}$ and we will not refurbish his findings here. The intent of this article is to examine method rather than theory or result. We do not survey the rules of due process or query their correctness. ${ }^{4}$ We do look at the process of prescribing those rules. We assess the prescribers' procedure, testing it for capacity to help ensure correct rules. Our presumption is that modest reforms may be practicable, that the process of prescribing due process could be bettered.

Many of the ideas discussed here relate to Hannah v. Larche, decided by the Supreme Court in June $1960 .^{5}$ It deals with the due process rights of subpenaed witnesses. The Umited States Commission on Civil Rights, having received accusations that certain Louisiana registrars had deprived

* Professor of Law, University of California School of Law, Berkeley.

1 Frankfurter, J., concurring in Hannah v. Larche, 363 U.S. 420, 487 (1960).

2 Douglas, J., id. 505-06 (einphasis added).

8 Kadish, Methodology and Criteria in Due Process Adjudication-A Survey and Criticism, 66 YALE L.J. 319 (1957).

4 "While Justice Cardozo in 1937 felt able to find the 'rationalizing principle' which gave 'proper order and coherence' to the determinations made up to that tine, the array of apparently disordered determinations since that date would no doubt give pause to one conteinplating a similar effort today." Kadish, A Case Study in the Signification of Procedural Due ProcessInstitutionalizing the Mentally $I l l, 9$ W. PoL. Q. 93 (1956).

8363 U.S. 420 (1960); 74 HARv. L. REv. 120 (1960). 
citizens of the right to vote, subpenaed those registrars to appear at a hearing and testify regarding the accusations. The registrars learned that the Counmission would deny rights of apprisal, confrontation, and crossexamination; so their lawyers obtained a court order enjoining the Commission "froin conducting the proposed hearing in Shreveport, Louisiana, whereby plaintiff registrars, accused of depriving others of the right to vote, would be denied the rights of apprisal, confrontation and crossexamination." " The Supreme Court then vacated the injunction, ruhing that in this kind of proceeding due process does not require that subpenaed witnesses be given those rights.

The opinions in Hannah v. Larche are a mine of information on the theory and practice of due process. They concern not nierely an injunction in Louisiana and the subpenaed registrars whom it protected. Subpenaed witnesses generally are discussed-not only Civil Rights witnesses, but those called by all other executive and administrative officials, by grand juries, by legislative investigating conmittees, federal and state. Specifically, the opinions have helped inspire these questions as to the process of prescribing due process:?

I. Should not the words of the due process clauses be re-examined for plain neaning?

II. Should not due process rights nore consistently be classified and distinguished from other constitutional rights?

III. Would not an analytical checklist aid the deciding of cases?

IV. Who could spearhead reform, how?

\section{I}

THE WORDS OF THE DUE PROCESS CLAUSES SHOULD BE

\section{RE-EXAMINED FOR PLAIN MLEANING}

The fifth amendinent declares, "No person shall . . . be deprived of life, liberty, or property, without due process of law ...." The fourteenth amendment (for our purposes here) is the same: "No state shall . . . deprive any person of hife, liberty, or property, without due process of law...." Those words are spongy and by themselves solve no problenis. Quite a few problems might be eased, though, if the words were given full content. We pose two illustrations: (1) the privilege doctrine; (2) the too pervasive criminal trial analogy.

\section{A.The Privilege Doctrine}

How should we read "life, liberty, or property"? "Liberty" has

6363 U.S. at 429 n.11.

7 The opinions are criticized in Newman, Due Process, Investigations, and Civil Rights, ...... 
attracted probably the most attention, and no doubt needs more. ${ }^{8}$ We are not even near the brave new world that might inhere in "hife." (Does it mean only freedom from death? How about "the good life," or what for some people "begins at 40 "?) Yet without soaring into semantics or political theory could we not shun one view of "life, liberty or property" that has caused much chaos? I refer to the hundreds, maybe thousands, of cases that protect "rights" but not "privileges," declaring that "due process of law is not apphicable [with respect to government employment, for instance] unless one is being deprived of something to which he has a right." I refer also to Hannah v. Larche, where the Court stated that the Civil Rights Commission "does not make determinations depriving anyone of his hife, hberty, or property ... and cannot take any affirmative action which will affect an individual's legal rights."10 When the facts that were before the Court are examined, when we see that the Commission-pursuant to congressional command-can and does sponsor pubhicity that may defame, degrade, and incriminate people, what the Court seems to have said is that governments, by derogatory publicity, do not affect "liberty, or property."

The due process clauses say nothing of right vs. privilege. The chief vice of the privilege doctrine is that it has insulated us from a body of law, highly reputable, that seems designedly apt for protecting the freedoms that "hfe, hberty, or property" appears to imply. I refer now to the law of torts, and the successful handling there of all legal interests. The torts cases teach us that "property" means more than land and chattels and choses-in-action; "liberty," more than freedom from physical harm and imprisonment. Why should those cases have outpaced due process cases? Why in private suits for damages or an injunction should legal interests be protected that due process leaves helpless? Examples are the interest in freedom from interference with reasonable economic expectancies, the interest in personal reputation and in freedom from disparagement, and the interest in freedom from emotional upset. ${ }^{11}$

8 E.g., see Nutting, The Fifth Amendment and Privacy, 18 U. PITT. L. REV. 533 (1957); Shattuck, The True Meaning of the Term "Liberty" in those Clauses in the Federal and State Corstitutions which Protect "Life, Liberty, and Property," 4 HARv. L. REv. 365 (1891); HAND, THE BIIL or RIGHTS 51 (1958) ("Liberty not only includes freedom from personal restraint, but enough economic security to allow its possessor the enjoyment of a satisfactory life."); Palko v. Connecticut, 302 U.S. 319, 327 (1937) ("biberty of the mind as well as liberty of action").

O Bailey v. Richardson, 182 F.2d 46, 58 (D.C. Cir. 1950), aff'd, 341 U.S. 918 (1951).

10363 U.S. at 441 ; and note the Commission's use of the quotation in Press Release $\$ 133$ (1961).

11 The technical terms are from $\mathrm{H}_{\text {ARPER }}$ \& JAMres, TORTS xii-xv (1956); cf. Prosser, Insult and Outrage, 44 CaLIs. L. Rev. 40 (1956); Prosser, Privacy, 48 CALIF. L. Rev. 383 (1960). See also Greene v. McElroy, 360 U.S. 474, 493 n.22 (1959); Anti-Fascist Comm. v. McGrath, 
The privilege doctrine should be junked, and "life, liberty, or property" should be treated as a description of all legal interests. To the question, "Won't you still have to define that last phrase?" the answer is, "Of course." But definitions can be guided by a bulk of precedents that makes far nuore sense than have judges' travails as to the rights of saloon keepers, dance hall operators, government employees, and aliens.

To pronounce that "liberty, or property" includes, say, reputational and eniotional interests would not niean that governnents no longer could deprive people of those interests, or that deprivations could be effected only by judicial trial. The requirement would nerely be that due process be accorded. With no trial and without a chance sometimes even to argue, people are often deprived of their property and liberty and even their lives; but in emergency cases, for example, due process is not necessarily violated.

Recognition of a due process freedon from disparagement or emotional upset would not require procedures the same as those which now protect a man's employment security, say, or his land. The nature of the interest must be taken into account. That is wlyy we demand special strictness for criminal proceedings, forfeiture proceedings, proceedings involving citizenship. That "life" and "liberty" and "property" are constitutionally conjoined does not mean that all interests therein merit identical protection.

In Hannah $v$. Larche the Court nuay wisely have decided that a certain Civil Rights hearing should not be proscribed, even though apprisal, confrontation, and cross-examination were to be denied. The Court's analysis would have been sounder, though, had it discussed differences between (1) a hearing that injures a witness by publicity which defames, degrades, or incriminates him and (2) a hearing that avoids those effects. In private law most courts have proved their fitness boldly to protect liberty and property interests. The Supreme Court is not honored by an implication that "Whatever procedure is authorized by Congress, it is due process as far as a witness who is nerely defamed, degraded, or incriminated at a hearing is concerned." 12

341 U.S. 123, 139 (1951); Rothbard, Human Rights Are Property Rights, The Freeman, April 1960, p. 23 ; Note, 65 Harv. L. Rev. 156 (1951) ; cf. Parker, Admunistrattve Law 36 n.36 (1952) ("The meagerness with which our problem-viz., what rights are protected by due process?-has been dealt is astounding.").

The best and most complete discussion of the privilege doctrine is 1 Davis, AdmINISTratrve LAW TrEatise $\S \S 7.11-7.20$ (1958). Professor Davis concludes, "Instead of two categories [right and privilege] we could have six or twenty, from the weakest privilege or absence of privilege to the strongest constitutional right. ..." Id. at 508. I prefer three categories: life, liberty, and property. Many interests are not legal interests and thus are not life, liberty, or property interests. Those that are, however (and I suggest the torts cases as guides), merit due process protection. That does not mean that the processes fit for allegedly subversive employees or allegedly knowledgeable witnesses must be the same as those for allegedly immoral aliens or the defendant in a criminal case. Cf. id. at 462 .

12 I have thus paraphrased a dictum in United States ex. rel. Knauff v. Shaughnessy, 338 U.S. 537, 544 (1950). For criticism of the analysis in the Hannah case see Newman, supra note 7 . 


\section{B. The Too Pervasive Criminal Trial Analogy}

The majority Justices in Hannah are to be commended for the breadth of their inquiry. Though the Louisiana registrars had been accused of crime, the Court in seeking analogies did not limit itself to criminal proceedings. It considered also the investigatory traditions of administrative agencies and of legislative committees.

Generally, judges (and scholars) assume too often that the criminal process is a model for other processes. We say, "Due process of course must be observed in civil as in crimmal trials, but since civil defendants are not alleged criminals some guarantees (e.g., proof beyond a reasonable doubt) do not apply." Similarly, licensees merit still lesser protection; and even less than that need be granted to prospective licensees, conscientious objectors, people who are mentally ill, government contractors, and parolees-all because they are not the accused in a criminal trial.

Consider the dictum that we test for due process by seeing whether procedures "offend those canons of decency and fairness which express the notions of justice of English-speaking peoples even toward those charged with the most heinous offenses." 13 Consider the recent cataloguing of the values involved in procedural due process as (1) "insuring the reliability of the guilt-determining process," and (2) "insuring respect for the dignity of the individual."114 The isolation of that second value is a major contribution to our understanding of due process, and may bring us great profit (see below). The first value, however, never should have been characterized as one circumscribed by "guilt-determining." What due process aims for is reliable truth-determining or, broadly, the reliability of the determining-making process. (We cannot use "decision-making" because it nray imply adjudication, broader than "criminal" but still too narrow.)

The due process clauses do not restrict all determination-making by government. They do apply whenever determination-making deprives a person of life, liberty, or property. The word "deprive" needs emphasis. It has no kinship to guilt. It does not imply, "No person shall be deprived [in the way alleged criminals in medieval England often were deprived] of hife, liberty, or property without due process." It rather must be read, "No person shall be deprived [in any manner whatsover] of life, liberty, or property without due process."

One gain might be that we no longer would measure public utilities, TV networks, social security beneficiaries, school teachers, and juvenile

13 Malinski v. New York, 324 U.S. 401, 417 (1945).

14 See Kadish, supra note 3, at 346-47; supra note 4, at 99. My criticism of Professor Kadish's ideas are meant to be tributes, not complaints. The process of prescribing due process might be aided immensely if scholars were more conscientious in building on the foundations occasionally laid by outstanding writings such as the articles of his I have cited. 
delinquents on the scale of procedural rights that gives 100 points to alleged murderers and zero points to an unwanted cabinet official. ${ }^{15} \mathrm{~A}$ related gain might be an awareness that due process sometimes should give people more rights than criminal proceedings ensure. The fact that pretrial discovery may be narrow in criminal cases, for example, hardly means that it should be no broader in hearings on license applications. Subpenaed Civil Rights witnesses should not be estopped from making a case for limited cross-examination merely because suspects before a grand jury may be demed that right. ${ }^{16}$

II

\section{DUE PROCESS RIGHTS SHOULD BE CLASSIFIED AND}

\section{DISTINGUISERED FROM OTHER CONSTITUTIONAL RIGHTS}

It is difficult to justify a brief filed in the Supreme Court that begins, "The question presented is ... the right of Congress or the [Civil Rights] Commission to violate under the 14th Amendment the rules of fair play and the traditional forms of fair procedure without explicit action by the nation's law makers even if it is possible that the Constitution presents no inhibition."17 Literate lawyers at the least ought not suggest that federal officials are ruled by the fourteenth amendment rather than the fifth.

It is also difficult, though, to censure illiteracies that could well be the result of the courts' fifth and fourteenth amendment confusions. Due process of the fourteenth amendment includes some Bill of Rights, nonfifth amendment procedure rules and some first amendment substantive rules, but not all of them. Fifth amendment due process includes some but perhaps not all of "equal protection of the law." Both cover void-forvagueness; but that doctrine has a unique role regarding the "preferred"

15 "The discharged cabinet officer may have a property interest in his job and in his reputation, but we want the President to have an unrestricted power to discharge him." 1 Davis, Administrative Law Treatise 454 n.7 (1958). Do Premier Ben-Gurion's recent struggles re Israeli Defense Minister Lavon suggest that Professor Davis may go too far? Should a cabmet officer be defenseless against findings of bribery or sexual immorality? If he could show there was no evidence against him, or no evidence other than the charges of a confessed liar, relief by way of declaratory judgment might well be appropriate. Cf. Gardner, The Great Charter and the Case of Angilly v. United States, 67 HARv. L. REv. 1 (1953).

16 There are many reasons why grand jury hearings are more protective than Civil Rights hearings. Cf. Note, 74 HARv. L. REv. 590 (1961). On the pretrial point, the Government argued in Hannah that "prehearing notice of the contents and sources of allegations made against thein-which plaintiffs claim is their constitutional right-is not even provided on the issue of guilt or innocence in Federal criminal prosecutions." Brief for Appellants p. 40. Civil Rights witnesses, however, do not benefit from pleading and trial traditions that protect alleged criminals. Also, they have not been indicted; and would it be wrong to assume that there would be less risk of their fabricating false evidence than of an indictee's?

17 Appcllee's Brief in Hannah v. Larche, pp. 1-22; and see p. 85 of the Transcript of Oral Argument ("the Fourteenth Amendment because they are denying them due process of law"). 
freedoms, and we never have decided whether it is really procedural or substantive. ${ }^{18}$

Overlaps are inevitable. But would it not help if rights claimed as constitutional were always, to the extent practicable, wrapped in the words that are most apt? Thus, if we seek a right not to be exposed by Congress or a right to be silent or to be let alone, we need very sophisticated analyses of article $I$ and the first amendment and the privilege against self-incrimination, as well as of residual due process. Relations between due process and the sixth and seventh amendments ("criminal prosecutions" and "suits at common law") need clarification too, as does the impact of the fourth amendment as well as due process on "compulsory extortion of a man's own testimony."19 Even within the fifth, what is due for grand jury proceedings may differ from the implications of "No person shall be held ... unless on a presentment or indictment . ..." And have we not learned enough about the privilege against self-incrimination to enable us to concede that we need not force a man to forfeit other protections (e.g., procedural protections) merely because he is about to be incriminated and thus may claim the privilege? ${ }^{20}$

To suggest that doctrine and arguments should be solidly based is far from startling, and I hope readers will not infer that next on the agenda is to be a criticism of the West Digest outlines. Are we not startlingly ignorant, though, as to the panoply of rules of due process? Have reasonably adequate summaries ever been constructed? Has any judge, scholar, or practitioner ever mastered those rules in the way that other law has been mastered (evidence, contracts, torts, and tax, for example)? Mere wishing for a summary or a Wigmore or Williston gains us little, but more imaginative building of large and small blocks of due process law could indeed be useful.

A distinction noted above illustrates the point. Some due process rules aim to insure the reliability of the determination-making process (e.g., rules requiring cross-examination and an unpredjudiced tribunal). Others aim at respect for the dignity of the individual (e.g., rules against stomach pumping and cruel pumshment). That classification could vitally affect due process semantics. "Fairness," for instance, must have an ingredient of efficiency when we test the first kind of rule (reliability) that normally could be absent in rules aimed at personal dignity. And judicial standards

18 See HaNd, The Bulx of Rights (1958); cf. McWhinney, The Power Value and Its Public Law Gradations: A Preliminary Excursus, 9 J. POB. L. 43 (1960).

10 Boyd v. United States, 116 U.S. 616, 630 (1886).

20 See the discussion on pp. 112-13 of the Transcript of Oral Argument in the Hannah case ("There might not be the necessity for pleading the Fifth Amendment if we were given the opportunity of presenting witnesses . .. "). But of. In Re Groban, 352 U.S. 330 (1957). 
such as "hardship so acute and shocking that our policy will not endure it" 21 and "protection of ultimate decency in a civilized society" ${ }^{22}$ seem to fit the second value better than the first.

The recent Davis Administrative Law Treatise supplies a more than ample base for classification. If its teachings as to the administrative process could now be integrated with comparable studies of court processes (including analyses of contempt procedure, for example, as well as police, mental health, and family court procedures, etc.) the prescribers of due process would gain immensely.

\section{III}

AN ANALYTICAL CHECKLIST MIGHT AID THE DECIDING OF CASES

Appellate courts are not an audience of law students. Yet their handling of due process cases might benefit from the kind of issue-finding checkist that has helped many law students analyze difficult examinations. For when the procedure of government officials is measured for compliance with due process, are not these questions relevant?

\section{A. Apart From Alleged Procedural Error, Exactly How Did Officials Harm (or Threaten to Harm) Complainant in this Case?}

We have seen that much may hinge on "deprive" and "life, liberty, or property." However interpreted, though, those words must be tailored to proved facts. Assume that courts do construe "liberty, or property" to include freedom from reputational harm. The precise interests jeopardized still must be identified in each case, as must the official conduct that caused the jeopardy.

In Hannah v. Larche the phrase "defame, degrade, or incriminate" was critical. Yet whether the registrars truly did risk defamation or degradation was pretty much left to inference, and the attorneys never did dramatize the ways in which the Commission threatened to deprive the registrars of the interests that inhere in freedom from defamation and degradation. Similarly, though the registrars had been subpenaed and thus risked injury required to be self-inflicted, ${ }^{23}$ language of the Court implies that subpenaed witnesses are no different from other people whom the Commission's activities might harm. ${ }^{24}$

The kind of precise portrayal of harm that may crucially affect a law-

21 Palko v. Connecticut, 302 U.S. 319, 328 (1937).

22 Adamson v. California, 332 U.S. 46, 61 (1947).

23 For an example of Commission-sponsored harm to reputation that had its origins in compulsorily self-inflicted injury see p. 5 of the Commission's NPR-44 (Dec. 12, 1958): "The election officials recited their excuse for not testifying in a halting manner, requiring coaching and prompting from their attorneys every four or five words."

24363 U.S. at 443 . I think this explains why the Court misconstrued the words of the injunction. Id. at $429 \mathrm{n} .11$ and $444 \mathrm{n} .20$. 
suit is exemplified by Petitioner's Brief in Peters v. Hobby. ${ }^{25}$ "We of course concede," said counsel, "that the Constitution does not limit the power of the executive summarily to terminate employment on secret information or for any other reason. The question before this Court is only whether the Government has the right to accompany a discharge with a finding of disloyalty which rums the reputation and career of the accused, without a full hearmg." ${ }^{26}$ In other words, the protested harm was not to job security but to one's repute as a prospective jobholder. ${ }^{27}$

\section{B. Exactly What Procedural Rights were Granted, Available, Denied?}

Phrases like "notice," "summary procedure," and "right to be heard" are of decreasing value in due process litigation. Sometimes because of their fuzziness they are provably misleading. Procedural rights are bands on a spectrum, and courts are led astray if they have to hazard a guess or examine the record microscopically to ascertain which bands merit attention. Too many briefs and opmions never tell us exactly what rights were granted the complainant, to offset those denied, or what rights might have been available had he made a timely request.

Hannah v. Larche is disturbingly illustrative. Apprisal, confrontation, and cross-examination are rights the Court held may be denied to witnesses. But with respect to cross-examination was it relevant that complainants could have submitted to the Commission questions to be put to their accusers? With respect to confrontation was it relevant that all accusers who were scheduled to testify could have been confronted? And with respect to apprisal what really do we learn from the Court's language: Were the subpenas sufficient? Was their vagueness illuminated by " 315 written interrogatories"? Is a chairman's "opening statement [of] the subject of the hearing" enough? Could complainants have been denied the right to hear or read what their accusers who testified had to say ${ }^{28}$

All conceivable rights need not be separately arrayed in each case, for red-penciling or blue-penciling as to grant, availability, and denial. A general arraying is useful, however, and for border zones helps compel the tougher analyses that too often are shunned. With an array, judges might even be able to unravel some three-dimensional complications. In Hannah, for instance, what should the Court have pronounced as to secret hearings (which in fact were prescribed by Congress)? If freedom from defamation and degradation is "liberty, or property," should due process for

25349 U.S. 331 (1955).

26 Brief for Petitioner, p. 10, Peters v. Hobby, 349 U.S. 331 (1955). Approval of counsel's concession should not be inferred from its quotation here.

27 Cf. Gardner, The Great Charter and the Case of Angilly v. United States, 67 HaRv. L. REv. 1, 21 (1953) ("the circulation of adverse opinions about Angilly's character was no part of the duty of the Collector's job").

28 For discussion see Newman, supra note 7. 
secret hearings require less severe rules than those for public hearings (as to apprisal, confrontation, cross-examination, and right to counsel, for exainple)? We are miles from solving that problein, ${ }^{20}$ and by overlooking the coinplainants' right to a secret hearing the Court in Hannah probably has made the solution more difficult.

Finally, an accurate charting of rights granted, available, and denied would assure cognizance of some worthy ideas that relate to the timing of judicial redress. In Hannah all the judges chose to avoid a holding as to ripeness and exhaustion of administrative remedies. But the fact that some issues may have been ripe ${ }^{30}$ does not mean that all procedural rulings were fixed. Secrecy vs. publicity; the Commission's use of nontestifying accusers; the value of submitting questions for the Commission to put to testifying accusers: those are sample issues the Court never faced. Yet its opimion will encourage too many readers to infer that due process requires none of the rights that proper analysis of those issues might ensure.

\section{To Decide the Case is it Necessary to Apply the Constitution?}

A settled doctrine requires that judges look critically at all statutes and regulations which allegedly permit a process that allegedly violates due process. " $[\mathrm{T}]$ raditional forms of fair procedure [Inust] not be restricted by implication or without the most explicit action by the Nation's lawmakers, even in areas where it is possible that the Constitution presents no inhibition." ${ }^{31}$ There are some traps for the unwary, but we shall not discuss them here because the matter involves statutory interpretation rather than due process.

Other doctrines that seem to be less used in due process cases could have a like impact. Do they merit more use? The doctrine of prejudicial error, for exanple, has a respectable history that Congress honored in the Administrative Procedure Act. ${ }^{32}$ It can be twisted by compelling a complainant to prove too much, and a concern for decent governing may require that it not affect certain cases (death penalty cases, say). But would not due process law generally profit from the kind of precise identification and measurement of procedural harm that we recommended above for sub-

29 Cf. the dissenting opinion in Hannah v. Larche, 363 U.S. 420, 496 (1960).

80 There are not many cases where, for threatened procedural irregularities, an agency hearing has been enjoined. 3 Davis, Administrative Law Treatise chs. 20 \& 21 (1958). The attack in the Hannah case was directed at procedural rules. They were "final agency action" within $\S 10$ (c) of the APA, 60 Stat. 243 (1946), 5 U.S.C. $\S 1009$ (1958); but query whether there was "no adequate remedy in any court." $C f . \S 105(\mathrm{~g})$ of the Civil Rights Act of 1957, 71 Stat. 636 (1957), 42 U.S.C. $§ 1975 d(g)$ (1958). The Solicitor General did not discuss this issue even though the Department of Justice had pressed it at the trial level.

31 Greene v. McElroy, 360 U.S. 474, 508 (1959) ; Clancy v. United States, 81 S. Ct. 645 (1961).

32 Supra note 30, § 10(e). 
stantive harm? Little damage can result from "Whatever the bounds of due process, complaint here has not been prejudiced."33

Another set of nonconstitutional inquiries pertains to cases where courts are not the aggressors against government (as when they enjoin hearings), but are rather the dispensers of power (as when their aid is sought to enforce subpenas or other agency commands). In Hannah it was held that due process did not authorize the enjoining of a Civil Rights hearing. Might the Court have been more solicitous of witnesses' rights had the appeal resulted from a lower court's refusal to enforce a Civil Rights subpena, rather than an order which made the lower court an aggressor? ? $^{34}$

D. If it is Necessary to Test for Due Process [and again note the need for checking, too, other clauses of the Constitution], What Authorities Have Approved, Disapproved, or Proscribed the

Questioned Procedure?

We need not fret here about stare decisis. Locating all the precedents may be troublesoine (because of the stunted progress on classification we mentioned above), but the course of due process precedent does not vary froin what seems set for most constitutional litigation.

What may distinguish due process cases is the density of nonjudicial precedent. At times, the quest for what courts have done seems almost incidental. That quest is now complemented by the inquiry, "What procedures have governments actually used in matters like this?" The Brandeis brief has a noble history, and its utility for subjects other than economic regulation is established. ${ }^{35}$ When it is launched full-blown into the fray of due process, however, it sometimes seems more akin to Stephen Potter and his gamesmanship than to a distinguished jurist and his drive for social reform.

The main trouble with non-court precedents in procedure cases is that they approach infinity. An important argument can begin, "In the FTC, $\mathrm{CAB}, \mathrm{NLRB}$, and Department of Interior, for example ... ." Or, "In 23 state public utilities commissions ...." Or, "In the juvenile delmquency

${ }^{33}$ Cf. Market St. Ry. v. Railroad Comm'n, 324 U.S. 548, 562 (1945). A prejudicial error doctrine would not be contrary to the Karl Llewellyn rule that "once there is a clearish light, a court should make effort to state an ever broader line for guidance." LLEWELLXN, THE CoMrzan Law Tradimon: Deciding Appeats 398 (1960). Does his rule, prescribed for appellate work generally, apply to all due process cases? I submit that the potential harm to government of cases that say "This and like procedures are bad" is much less than the potential harm to citizens of "This and like procedures are permissible." ( $C f$. the Hannak case.) The reason is that officials tend to push the borderlines to the citizen's disadvantage in both situations.

34 Cf. United States v. Kleinman, 107 F. Supp. 407, 408 (D.D.C. 1952).

35 See 2 Davis, Adirnmstrative Law Treattse 354 (1958); cf. Doro, The Brandeis Brief, 11 VAND. L. Rev. 783 (1958). 
proceedings surveyed by the editors of the Indiana Law Review ...." Or, "In Queensland, Northern Ireland, and Pakistan ...." Or, "Compare [or contrast] the long-established practices as to allegedly insane criminals in France, Norway, Nazi Germany, and/or Soviet Russia." And historical inquiry adds a vast dimension of time to that of geography.

The Court in Hannah v. Larche thought it "highly significant that the Commission's procedures are not historically foreign to other forms of investigation under our system." 36 We are then invited to consider:

1. "The first full-fledged congressional investigating committee. . . . The development and use of legislative investigation by the colonial governments. . . . The English origin of legislative investigations in this country. ... The English practice [now]...."

2. A "vast majority of instances ... [where] congressional committees have not given witnesses detailed notice or an opportunity to confront, cross-examine and call other witnesses."

3. "The history of investigations conducted by the executive branch of the Government ...."

4. Processes of the FTC, SEC, AEC, FCC, NLRB, OPS, OPA, FDA, Department of Agriculture, Tariff Commission, and "many of the most famous presidential commissions."

5. "[T]he oldest and, perhaps, the best known of all investigative bodies, the grand jury ...."

That is an impressive list-though more agencies could have been added, of course, as well as state and commonwealth precedents.

What causes pause is that the research required to document that kind of survey can be quite taxing. And there is evidence that the lawyers and clerks who aided the Court in Hannah did not tax themselves sufficiently. ${ }^{87}$ Public administration research and historical and comparative research demand a scientific method; and findings that are accurate, complete, valid, and reliable are not easily assured.

The decade of the 1960's is hardly a time for arguing that tough due process cases should be decided without reference to the practice of other tribunals, other governments, other eras. We must recognize, nevertheless, that the data collected will tend to be anecdotal even if they are trustworthy. "[T]he considerations of fairness that reflect our traditions of legal and political thought..." 38 are often elusive, and the amassing of citations which purport to illumine those traditions sometimes adds little light indeed. ${ }^{39}$

36. 363 U.S. at 444.

${ }^{37}$ See Newman, supra note 7.

38 Frankfurter, J, concurring in Hannah v. Larche, 363 U.S. 420, 487 (1960).

39 Professor Kadish perceptively describes and evaluates the "criteria for interpreting a flexible due process." Kadisb, Methodology and Criteria in Due Process Adjudication-A Survey and Criticism, 66 Yate L.J. 319, 327, 344 (1957). He concludes, "the Court has [regarded] ...its function as one of passively applying moral judgments already made, rather than as one 


\section{E. Exactly How Would Efficiency be Affected, in This and Similar Proceedings, if Complainant's Request were Allowed? (Herein of deference)}

Even if "traditions of legal and political thought" have been revealed, they need be "duly related to the public interest Congress sought to meet ... as against the hazards or hardship to the individual that the ... [attacked] procedure would entail." ${ }^{40}$ Gospel truths are that due process shields us from other public interests and that the other interests give way whenever "the hazards or hardship to the individual" loom too large.

This article will not explore the issues of deference and balancing that perplex judges when they apply first amendment due process, or aim to ensure "respect for the dignity of the individual." those issues demand the same articulation when judges seek to preserve what we labeled above "the reliability of the determination-making process." If the public interest, for example, is to keep movies clean and to imprison dope addicts, prior censorship and stomach pumping may or may not be constitutional, given a court's view of fundamental rights and individual dignity. But prior censorship and stomach pumping, per se, are not unreliable. They can be efficient truth-determining techmiques, whether or not lawful.

When we permit censorship and testing of the human body, lowever, the procedures often must be checked for reliability. Thus, each exhibitor ought to be allowed to argue that his movie slould not be censored, and the questioning of plyysiologists' techmiques (e.g., on blood tests) should be permitted, because we know that arguing and questioning may well expose error arising out of those procedures. ${ }^{42}$

of actively making new moral decision." Id. at 344. He does not fully explore "whether the Supreme Court is institutionally equipped to ascertain and evaluate the complex factual data necessary for rational decision-making." Id. at 359. But his inquiries into "the data of comparative legal systems" (p. 354) and "the use of knowledge outside the record" (p. 359) lead me to wonder, Are mountains of data ever likely to be truly as enlightening as an insistent foctus on good sense? He searches for "the effect of an added risk of misdeterminations if certain procedures are sanctioned, and ... the effect of not permitting an attenuation of those procedures." (p. 353) That is a scholarly definition of what I have loosely labeled "efficiency." In the Hannah case, I believe, the Court was so bogged in data that its members never did exploit their own good sense on how complainants' requested rights might have affected the efficiency of the Civil Rights Commission. Another example is Anonymous v. Baker, 360 U.S. 287 (1959). Since the investigator there "expressed his readiness to suspend the course of questioning whenever appellants wished to consult with counsel" (id. at 28), exactly how would efficiency have been hurt if counsel had been allowed to observe the proceedings?

${ }^{40}$ Frankfurter, J., concurring in Hannah v. Larche, 363 U.S. 420, 487 (1960).

41 See HaNd, The BIII of Rights (1958).

42 On blood tests, compare the court of appeals opinion in United States ex rel. Lee Kum Hoy v. Shaugnessy, 237 F.2d 307, 308 (2d Cir. 1956) ("the data . . . established conclusively that Lee Ha could not be the father"), with the Supreine Court's per curiam notation that remand was necessary because "the blood grouping tests made herein were in some respects 
What truly is the public interest in procedure itself (or, more precisely, in the procedures that may lead to depriving people of their life, liberty, or property)? Is it not to ensure that correct determinations will be made (and thus only the deserving deprivations be effected), except where some margin of error seems essential to avoid ills that inhere in procedure (e.g., cost and delay)?

To illustrate: The public interest in censoring dirty movies might be jeopardized if the only available procedure were trial by jury; and too few drunk drivers might be punished if every government breath-tester could be subpenaed and cross-examined as to the conditions surrounding his breath-test. Yet censors and testers err, as do all government officials; and centuries of revolution and war warn us that too much error is intolerable. The problem is to set the margin of tolerable error, given the ills of too much procedure. (That margin is usually minimized, of course, by the inventiveness of law men who demonstrate that devices such as preliminary injunctions can avoid the harm of dirty movies, pending a truthseeking trial, and that allowing a man's own doctor to repeat a health offcial's test is a check on accuracy that raises hardly any of the questions which trouble us as to cross-examination of health officials.)

In due process cases there are these critical questions: (1) Exactly how would "efficiency" be affected, in this and similar proceedings, were complainant's request for procedural rights allowed? (2) Should courts make that determination or should other officials?

The Civil Rights Commission's assignment is to submit reports to the President and the Congress. Those reports are to "appraise the laws and pohicies of the Federal Government with respect to equal protection of the laws," and the Commission is directed to "study and collect information concerning legal developments constituting a denial of equal protection of the laws." The public interest is manifest; and efficiency would suffer if the Commission, after it had studied sociological and statistical reports and law review articles, say, were required to notify interested citizens of a grand hearing to be convened at which the authors of those reports and articles could be cross-examined. The band of Commission error that thus might be exposed is far less significant than the obvious ills of that procedure; and the right to petition the Government (as well as advising one's legislators, participating in congressional hearings, etc.) seems sufficient for keeping the margin of error low.

The Commission is further directed, however, to "investigate allega- 
tions in writing ... that certain citizens of the United States are being deprived of their right to vote and to have that vote counted by reason of their color, race, religion, or national origin; which writing, under oath or affirmiation, shall set forth the facts ..." The public interest iniplied in that directive relates to evil-doing - the kind of evil-doing that may first, persuade Congress to enact law; and second, persuade the President that he should either (A) encourage Congress to enact law, or (B) advise his Attorney General or other subordinates of a possible need for appropriate action. Quite clearly, Congress no longer was satisfied with the type of informal accusations that normally are adequate for legislating. Apparently too, Congress was not satisfied that the Attorney General and other policemen knew enough about existing violations of law. So sworn accusations were called for, setting forth "the facts"; and the Commission was directed to investigate them. As Lyndon Johnson said on the floor of the Senate, "It can gather facts instead of charges; it can sift out the truth from the fancies ...."

What of efficiency? During the year ending in August 1959, the Commission received approximately 240 accusations involving 29 counties in 8 states. $^{44}$ By February 1960, at least 86 more had been filed, involving four additional counties. ${ }^{45}$ The Commission favors "full investigations," which apparently means careful study, field interviews, and-on rare occasions-hearings. This seems clear: To advise every accused evil-doer that he has been accused, to tell him who accused him, and/or to permit him to cross-examine his accusers might be too complicating, too delaying, too costly.

What if the accused is subpenaed, however, to testify regarding an accuser's testimony at a public hearing? Would it be inefficient to let him know generally what the Commission was after, what kind of examination he would be expected to face, what evidence he should be ready to produce? Would it be inefficient before he testifies to let him sit with the public as a spectator? Would it be inefficient to allow him a limited right of crossexamination, or to submit questions for the Commission to put to his accusers?

Those are questions Hannah v. Larche did not answer, and they illustrate a variety of questions that ought to have been answered. They relate to the reliability of the determination-making process. One can ask whether the margin of error that might have been minimized by the rights postulated, for that kind of Civil Rights hearing, would truly have been offset by the ills that sometimes might accompany such rights.

43103 Cong. REC. 12637 (daily ed. Aug. 7, 1957).

441959 RePORT OF THE COMMnission ON CrVIL RIGHTs 55.

45106 Cong. Rec. 3405 (daily ed. Feb. 27, 1960).

461959 Report of the Comarission on CivIL RigHts 55. 
That weighing of procedures' efficiency leads to the question, Who decides? When should courts defer to the judgment of the legislature? Of the chief executive? Of cabinet officials? Of policemen, prosecutors, prison wardens, psychiatrists? If we sought only "the considerations of fairness that reflect our traditions of legal and political thought, duly related to ... the hazards or hardship to the individual that the ... [attacked] procedure would entail," judges ought to be paranount. ${ }^{47}$ When we also seek "the public interest," however, so that it too can be balanced with the traditions and the individual's interest, efficiency is the new ingredient. The play between procedure and the goals of government becomes crucial, and the epic of administrative law-in New Deal years especially-resounds with reminders that courts' views of efficiency are often believed to be heedlessly frustrating. Even so, the case for deference by judges is weakest when procedural due process is at stake; and these observations seem noteworthy:

First, the legislature is often the antagonist in litigation that involves economic controls, equal protection, censorship, and other substantive questions. In procedural due process cases, contrastingly, courts hardly ever have to declare a statute unconstitutional. For legislatures rarely say, "This is the procedure we want used." Instead they broadly delegate procedure-making authority, and the result is that courts then war with lesser bodies than the legislature itself. Even when a statute is voided that says to an agency, "You may if you wish deny the right to cross-examine," the effect is different from the voiding of a statute providing, "Cross-examination must not be allowed, for the public interest then would suffer." That latter statute is atypical.

Second, admimistrators (and investigating committees, grand juries, and in fact all lesser officials with jobs to do) have demonstrated, I think, that they are less trustworthy with respect to procedure than are judges. I refer not merely to the abuses of loyalty-security, the pillorying of peoples' reputations, illegal police practices, or other histories of arbitrary action. Nor would I add only the reminder of Justice Douglas in Hannah that "Men of goodwill, not evil ones only, invent, under feelings of urgency, new and different procedures that have an awful effect on the citizen."148 I am unore influenced by the fact that administrators too often have cried,

47 But cf. Norwegian Nitrogen Prod. Co. v. United States, 288 U.S. 294, 321 (1933): "[S]ince a hearing is required, there is a command by implication to do whatever may be necessary to make the hearing fair. A duty so indeterminate must vary in form and shape with all the changing circumstances whereby fairness is conditioned. The appeal is to the sense of justice of administrative officers, clothed by the statute with discretionary powers. Their resolve is not subject to impeachment for unwisdon without more. It must be shown to be arbitrary."

48363 U.S. at 507. 
"Wolf, wolf!" Too often, for example, have government attorneys pleaded that to grant rights requested by the complainants would wreck their agency's program-when, following defeat in court, it becomes obvious that the threats were posh. Even in the Suprene Court, where governments have such great resources for winnowing out their borderline cases, is it not astonishing that the Sohcitors General (and their state counterparts) so frighteningly often have been wrong on what fundaniental fairness requires? And how inadequate, empirically, have been their hundreds of awful-consequence predictions regarding the efficiency and effectiveness of government business!

Judges are sometimes wrong, too. And it may be that a few decisions are nuaking a few criminals' lot a happy one, or that appellate judges as a group still are too eager to impose court rules on agencies whose tasks call for a modified process and a freedom to experiment. In bulk, though, the sins of judges who ained to ensure due process surely have been overbalanced by the sins of bureaucrats who-conscientiously, vigorously, in good faith we assume- seek means that at first glance appear the least disruptive to their immediate ends. Too few administrators have acknowledged that "due process of law is not for the sole benefit of an accused... [and] is the best insurance for the Government itself against those blunders which leave lasting stains on a system of justice.... ${ }^{49}$

\section{IV}

\section{WHO COULD SPEARHEAD REFORM, HOW?}

The people who prescribe due process are nearly always adjudicatorsadministrative or judicial. In their adjudications they examine procedure to see if it is constitutional. On occasion, agencies and trial judges set the law of due process (e.g., when a body like the NLRB declares, "No less than this does due process require."). But appellate courts are paramount, of course; the Suprene Court, pre-eminent. Inevitably this article treats of that Court's problems. Its process for prescribing due process is emulated by other prescribers, and the target of reform is there if the process be deficient.

40 Shaughnessy v. Mezei, 345 U.S. 206, 224-25 (1953) (dissenting opinion); cf. Gellhorn, Changing Attitudes Toverd the Administrative Process, in INDINIDUAL FrEedOM AND GoverNMENTAL RESTRAINTS ch. 1 (1956). For further comment on deference and due process see Kadish, Methodology and Criteria in Due Process Adjudication-A Survey and Criticism, 66 Yale L.J. 319, 358-59 (1957); cf. id. at 337 n.114 ("In the area of procedural due process ... [Justice Frankfurter] seems to be asserting a doctrine that increases, rather than decreases, the latitude of discretion open to the Court in adjudicating constitutional issues."). Learned Hand, who recently admonished that the courts' duty of deference must not be denigrated, seems to categorize procedural due process separately. HAND, THE BIIL OF RIGETS 44-45 (1958). Is it significant that the widely distributed Preface to Davis, Administrative LAw Treatise (1958), which documents Supreme Court misfeasances by citing chapter and verse, complains of no procedure cases? Cf. 2 id. $\$ 16.10 ; 1$ id. 471 (discusses efficiency without mention of deference). 
Whether legal writings point the way to reform is not always a test of their utility. Some of the best do not aid reformers but rather contribute to knowledge, understanding, or their readers' enjoyment. Yet aid to reform is a valued goal, and provides an interesting test for what Erwin Griswold has called "the current chapter in the long history of criticism of the Court."

The inessage in most of the newer criticism is that the nine Justices who comprise the Court themselves bear responsibility for its ills. If we imagine, for instance, a conscientious, newly appointed Justice who is eager to fashion the image toward which he should strive, he would learn from careful study of the recent critiques that he and his colleagues should be wiser, Inore lawyerlike, inore statesmanlike, more perceptive, more efficient, less dilettante, less opinionated, more or less worldly, more or less consistent, inore or less unanimous, et cetera. (He would also learn that the inere reading of all those books and articles probably fouled up his time chart.)

Here we deal only with procedural due process, and that topic is not How the Court Should Manage Its Business or How the Court Should Handle Constitutional Law. But we have considered reforms, and an identifying of possible reformers seems fitting. What is clear is that WE WILL DELUDE OURSELVES IF WE ASSUME THE COURT ALONE HAS THE BURDEN OF IMPROVEMENT.

Questions this article has posed relate, for example, to "good lawyering." Is not that attribute one which in the Court is far more institutional than personal? Are not craftsmanship and understanding far less dependent on the conscience and will of nine Justices than on the presented product of counsel, trial courts, law clerks, other participants? In Hannah, for instance, though the case was terrifically complex, the opinions and the Justices' cominents in oral argument show an awareness of issues and of law that was nowhere near inatched by counsels' briefs or arguments. Who, then, is to blame for missing some of the subtle points discussed above (particularly when we see that Hannah was announced the same day as Aquilino, Durham, Locomotive Engineers, Annheuser-Busch, Metlakatla, three Steelworkers cases, Flemming v. Nestor, Miner v. Atlas, Schilling, American-Foreign Steamship, Hudson, and Cory Corp. v. Sauber $\left.{ }^{51}\right)$ ?

Thurman Arnold's comment that the Supreine Court opinions "rank higher than the articles which appear in the Harvard Law Review" is worth pondering. ${ }^{52}$ Do not current attacks on the Court, even when "based

50 Griswold, Foreword: Of Time and Attitudes-Professor Hart and Judge Amold, 74 HARv. L. REv. 81, 82 (1960).

51 See 363 U.S. 509-721 (1960).

52 Arnold, Professor Hart's Theology, 73 HaRv. L. REv. 1298 (1960). 
on understanding and respect and designed to assist the Court with its great and difficult task in our constitutional system," 53 tend to reach for a perfection that no nine Justices, law professors, Wall Street lawyers, or men or angels could ever attain? Improved lawyering and sounder analyses and new lines of inquiry and efficient procedures must be institutional goals. Our worst sin as critics has been an unscholarly premise that some outstanding men named Warren, Frankfurter, Black, et al. somehow should take on an assignment that in fact inust largely be ours and many others'.

The problem of court reform is reminiscent of problems of influence peddling. There the initial cry was for improved ethics in the regulatory agencies. Then it became clear that the issues were really quite complex and that some of the boldest critics-Congressmen and lawyers-were themselves deeply involved. Influence peddling problems still are mostly unsolved; but we have learned that agencies' codes of ethics are only piecemeal solutions, and that self-reform within Congress and the bar may be much more critical.

Consider similarly the aches of investigating committees. We first pitted the good guys against the bad and hoped that sensible middlemen (Senators George and McClellan, say) would restore law and order. Then we discovered that voters and newspapermen and thus politics were involved, and that fair committee procedure called for sophistications which only members of the bar could supply. The response of lawyerplanners and lawyer-draftsmen was excellent; and if more lawyer-statesinen had responded comparably (with the kind of lobbying campaign that is now being waged for professional men's tax benefits, say), we might have achieved for investigating committees a more impressive code than the House of Representatives' Fair Play Rules. ${ }^{54}$ (And who knows what impact that victory might have had on Hannah $v$. Larche ${ }^{35}$ )

The influence peddling and investigating committee analogies show what can be done when less attention is given to "Here is what you the commissioners (or you the Congressmen) should do" than to "Here is what we the lawyers inust do." The procedures of Congress provide a model too where critics finally realized that "Here is what we the professors must do." The Legislative Reorganization Act of 1946 is in large part a product of political scientists, after years of learned but unheeded scholarship as to legislatures' organizational deficiencies. ${ }^{56}$

53 Griswold, Foreward: Of Time and Attitudes-Professor Hart and Judge Arnold, 74 HaRv. L. REV. 81 (1960).

54 See Newman, Some Facts on Fact-Finding by an Investigatory Commission, 13 Adnms. L. REv. (1961).

55 Cf. Newman, sutpra note 7.

56 See Galloway, The Operation of the Legislative Reorganization Act of 1946, 45 AMr. Por. Scr. Rev. 41 (1951). 
Institutionally what might be done to improve the process of due process? As noted above we need a superior literature, which presses for precise definitions and what Karl Llewellyn calls "the structuring of whole fields and ... the sweating of clarity out of tangled lumps of five or fifteen or fifty or a hundred and fifty cases.... [For] it is the scholar who must carry the load first of stumppulling and then of dreaming or sweating up intelligible tentative drafts of sound design." ${ }^{267}$ The need for that literature (and for efficient guides to its use, instead of our self-deceiving Index to Legal Periodicals) should help keep us lumble. No one can pretend, how* ever, that the need is likely to inspire any foundation-sponsored or other project that in the foreseeable future could bring us closer to a better dueprocess process.

For measurable gain we must seek less remote proposals, such as Dean Griswold's suggestion that "the bar should take the lead in developing legislation which will reduce the burden on the Supreme Court." 158 The proposal I discuss now relates to the bar, particularly to traditions of advocacy that seem fixed for due process litigation (and, I suppose, most Court litigation).

If we must identify the mortal sinners in the due-process prescribing process, I nominate the lawyers for plaintiff and defendant. Their time chart is less compulsive than the Justices'; and they surely are most at fault when items on the checklist are unchecked, when exact harns, exact procedures, exact precedents are unidentified. A choice excerpt from one of the Hannah briefs (confusing fifth and fourteenth amendment due process) was quoted above. A score or more other excerpts would be equally damning. At oral argument why was the Court misled, for instance, as to the practices of congressional committees, the understanding of the Commission as to its duties re executive sessions, the Commission's interpretation of "defaine, degrade, or incriminate"?

The plain truth is that the Court does not benefit from what excellent advocacy could ensure, just as it does not benefit from what excellent scholarship could ensure. The temptation, therefore, is to conclude that lawyers must study the facts and law more carefully, write better briefs, prepare more painstakingly for oral argument. Unhappily, that has the same unreality as does telling scholars that the quality of texts and articles ought to be improved. Of course we need superior advocacy, but recognizing the need does not make the prospects of improvement less remote.

57 Lieweityn, The Comaron Law: Deciding Appeats 346 (1960).

58 Griswold, Foreward: Of Time and Attitudes-Professor Hart and Judge Arnold, 74 Harv. L. Rev. 81, 85 (1960); cf. Arnold, Professor Hart's Theology, 73 Harv. L. Rev. 1298, 1300 (1960) ("How Professor Hart proposes to reform the bar he does not say.").

59 See pp. 43-45, 50-58, and 93 of the Transcript. 
So, again, are we reduced to pontification that the true call is for a better bench, a better bar, better law schools-just as some critics argue that to control influence peddling and investigating committees we must elect better legislators and hire better men in government? One hopes that less radical cures might be developed; and it is with respect to advocacy that one cure might be practicable, $I$ believe.

When due process is prescribed, law is made-procedure law. Facts and arguments which influence that law making are in part the same facts and arguments which would have influenced non-court law makers-legislatures, agencies, judicial conferences, other groups that reform procedure law. The techniques for presenting facts and arguments, however, are phenomenally dissimilar. For in the process of prescribing due process we rely almost entirely on the talents and resources of two parties' lawyers.

To the comment, "Isn't that true for all judicial lawmaking?" I must reply, "Yes." And perhaps the process of all judicial lawmaking needs reforming, so we could bring to judges the wisdom and insights that are the product of procedures in statute-making and rule-making. I stress, though, three facts that may call for accelerated action on due-process process.

First: In due process cases most private lawyers do not enjoy the competence that inay mark their presentation of other cases. As a result, courts do not benefit from the high-quality lawyering that can aid tax law, labor law, criminal law, the law of the press, other subjects. Even civil liberties lawyers tend to be better informed on first amendment rights than on most due process rights.

Second: Government lawyers, on the other hand, are able to acquire due process expertness; and the fee and expense limits that in many cases confine private lawyering are not paralleled in government. The two teams of lawyers, therefore, are not evenly matched; and the courts suffer. If government advocates were statesmen, fit to guide judges wisely througl labyrinths of righteousness, their competence would be a blessing. The facts, sadly, show that Solicitors General and their counterparts are not permitted sucl a role. For their counsel is sought not when other officials wish to design a procedure, so that the lessons of "the very essence of a scheme of ordered liberty" may be put to good use. Rather they answer calls of alarm. They are shock troops to be rushed in when a lawsuit impends. Their job, with awful consistence, is to demonstrate that a procedure already set is really legitimate, though they and other lawyers (and people who designed the procedure, even) might now concede that de novo a more fair procedure should have been designed. ${ }^{60}$ One shudders at the

60 I have been advised that the government lawyers responsible for arguing the Hannah case were so set on victory that they sought out potential amici (who were contemplating the filing of a brief possibly like the Douglas-Black dissent) and persuaded them not to file. 
thought of the arbitrary governing that now might be our heritage if judges, year after year, decade after decade, had been overly impressed by the due process expertness of governments' advocates.

Third: Procedure (the kind of procedure that is used to deprive people of life, hiberty, and property) is peculiarly a lawyer's topic. In other fields there are busmessmen and churchmen and doctors and engineers for whom lawyers speak. Those people can be concerned with procedure, but even when substance is deeply affected (as in the commitment of juvenile delinquents or the mentally ill, say) the legal profession does not forfeit its eminence.

In typical cases, however, lawyers for the man deprived of life, liberty, or property may share too little of their whole profession's lore; lawyers for the Government, too much. Should not courts ensure a better balance by seeking from the profession aids to wisdom that the bar as a whole (lawyers and professors) could provide?

The best discussion of Extra Manpower that I know is Karl Llewellyn's; and his comments on "the lower courts and counsel," "the judge's law clerk," and "outside experts" merit attention. ${ }^{61}$ I wish he himself had given more attention to the amicus brief. "[R] equesting or inviting, on occasion, an amicus brief ... has been little institutionalized," he says, "and if institutionalized unwisely it could turn into an abuse; but the idea has much merit, for occasional use, especially when light is needed on situations technical and relatively unfamiliar to the court."

He wrote mostly of private law. With regard to due process law, for which the bar has a unique bent, should we be so cautious? A flood of amicus briefs might rub rawly too many sensitive issues in commercial law, perhaps, or all constitutional law. But one of these days we will have to face up to the arbitrariness and need for a right to petition and right to be heard in judicial lawmaking, ${ }^{63}$ and is not due process a fertile first field for experiment and expansion?

Why should not lawyers and law professors-individually, for clients, for ABA, AALS, ACLU, and other groups, for governments-articulate via amicus briefs a concern with due process procedure law that matches

01 Lieweliyn, The Comaron Law: Deciding Appeais 317-32 (1960). Some of the most objectionable language in the Court's Hannah opinion was inspired by pp. 18 and 35 of the Government's Brief. See text preceding note 10 supra.

62 Liewellyn, The Comanon Law: Decining Appears 323 (1960).

63 See Weintraub, Judicial Legislation, N.Y.L.J., Mar. 19, 1959; cf. Mitchell v. Trawler Racer, Inc., 362 U.S. 539, 571-72 (1960) (dissenting opinion); Wyatt v. United States, 362 U.S. 525, 535 (1960) (dissenting opinion); NLRB v. E. \& B. Brewing Co., 276 F.2d 594 (6th Cir. 1960); George R. Currie, Appellate Courts Use of Facts Outside of the Record by Resort to Judicial Notice and Independent Investigation, 1960 WIS. L. REv. 39. 
their variously demonstrated concerns with all other forms of procedure law? We have taught ourselves that committee reports and scholarly writings, alone, do not sufficiently influence lawmakers and that reform activity, to be fruitful, has to be packaged efficiently. For courts is not the best package-comparable to appearance at a legislative or rule-making hearing or an office conference with legislators or administrators-the amicus brief?

What would such briefs add? The writers could be lawyers whose interest was not confined to (1) this particular case, or (2) ensuring victory for the Government in this and similar cases. Their contribution could reflect some of that maturing of collective thought which perhaps cannot be assured by the bench itself. ${ }^{64}$ They could test counsels' arguments for compliance with the checklist (which thereby would become sharper, more complete, more useful). They could supply the breadth of view we need to expose privilege doctrines, too pervasive criminal trial analogies, and other doctrinal dead ends. Their ideas would not be molded to victory or defeat, ${ }^{65}$ and their grand strategy less likely would involve aims extraneous to due process. ${ }^{60}$ They could also focus for courts' attention some rather good ideas in legal writings that now, too often, are entombed. (In Hannah the opimions cite none of the leading texts or articles on cross-examination, and ouly one of the scores of recent articles that discuss investigating committee procedures.)

Those are potential gains, speculative but not insignificant. They might call for some management planming, though by no means do I recommend any souped-up, centrally controlled, amicus brief filing body. ${ }^{67}$ Free enterprise and sometimes even brashness are to be encouraged (which, incidentally, may require for academic life a vigilance to be sure that yonng teachers do not write articles instead of briefs merely to get their publishor-perish credits).

\section{CONCLUSION}

In short, the due-process process calls for alertness as to the deficiencies of both doctrime and mechamics. It calls for awareness that the job of

64 Cf. Hart, Foreword: The Time Chart of the Justices, 73 HARv. L. REv. 84 (1959).

65 While preparing a mock petition for rehearing in the Hannah case I discovered that my avowed "concern for rationality in the law of due process" was consistent with neither appellants' nor respondents' aims. Both sides would liave opposed my suggested conclusion. See Newman, supra note 7.

60 In the cold war now being waged on desegregation and other racial issues, what really are the stakes in a dispute regarding technicalities of the procedure of one not very powerful federal investigatory agency?

67 Cf. Freedman, Promoting the Public Welfare: A Proposal for Establishing a People's Advocate, 43 A.B.A.J. 211 (1957) ; Kadish, Methodology and Criteria in Due Process Adjudication-A Survey and Criticism, 66 YaIE L.J. 319, 363 n.198 (1957) (references to "a research body which would make determination of constitutional facts"). 
whittling away at those deficiencies is too vast for nine Justices. Reforms that a thousand others of us must effect are needed, and an expanded amicus tradition might be one useful reform.

The Justices bear some responsibility. When parties' briefs are insufficient postponements can be ordered; and there are nuany precedents where the attorneys have been directed to discuss Court-framed questions, where agencies have been asked to interpret documents or describe their practices, where comments of independent counsel have been sought. The Court might even impose some minimum standards for due process advocacy, to ensure that lawyers do not ignore items on a checklist or that they detail their quarrels regarding fact (adjudicative and legislative) as well as the law theories they espouse. Especially, the Court should not jeopardize its own due process by restrictive application of its amicus rules. ${ }^{08}$ It is not a committee of Congress, and it owes no duty of graciousness to all advocates who may wish to file or read statements. It is part of "the Government," nonetheless, and "to petition the Government" for better due process law (whether or not a first amendment right) is a right the Court surely should encourage when its own work might profit.

A final word relates to social significance. With respect to procedure law in general, it can be argued that appellate courts are not the best forum for reform and that reformers' himited energies, therefore, should be aimed at revised statutes, revised regulations, revised court rules. That is certainly true as to civil procedure and a great deal of criminal and administrative procedure. The big regulatory agencies, for example, rarely have any due process troubles; and a whole new Administrative Procedure Act can be drafted with only minor reference to the rules of due process.

There are immense areas of government, however, where much law is due process law-where crucial statutes, regulations, and rules are either nonexistent or unconstitutional. Many crimmal proceedings, loyalty-security proceedings, mental health proceedings, traffic court, juvenile court, and family court proceedings illustrate the point. The officials engaged in those activities are not constantly perturbed by due process opinions, but there is ample evidence that those opinions do have an enormous impact. ${ }^{60}$

68 Cf. Knetsch v. United States, 81 S. Ct. 132, 137 (1960) ("Some point is made in an amicus curiae brief of the fact that ... [petitioner] in entering into these annuity agreements relied on individual ruling letters issued by the Commissioner to other taxpayers. This argument has never been advanced by petitioners in this case. Accordingly, we have no reason to pass upon it."). Would more flexibility on rehearings be desirable? $C f$. Louisell and Degnan, Rehearing in American Appellate Courts, 44 CALIF. L. REv. 627 (1956). Generally, see Swisher, The Supreme Court and the "Moment of Truth," 54 Arr. Por. Scr. Rev. 879, 884 (1960).

69 Two years ago, reviewing the Davis Administrative Law Treatise, I stated that "Agency rule makers and adjudicators do pay considerable attention to statutes, but if Professor Davis believes they are regularly influenced by Supreme Court opinions I believe he is unistaken." Newman, The Literature of Administrative Law and the New Davis Treatise, 43 MINN. L. REv. 
Yet even more critical than an impact on administration is the impact on reform itself. We tend to regard due process opinions mostly as warnings to policemen or trial judges or agency officials-telling them what appellate courts won't let them do. Those warnings themselves effect many reforms. (E.g., "We'd better cliange the rules, because Olympus says we're not supposed to do that anymore.") The greater effect, though, pertains to statutes, regulations, and rules that are new and more comprehensive. ${ }^{6 \theta}$ Reformers of those less explored proceedings I just mentioned (loyaltysecurity, traffic court, juvenile court, etc.) do not only inquire "What inust we avoid to keep the new procedures constitutional?" They also ask, "For ideas as to procedure why don't we consider the due process precedents?" And often they add, "Why as a matter of policy should we require more than due process requires? For the cases tell us what is 'fair,' and who are we to seek more than fairness?"70

Hannah v. Larche, for example, reminds us that "due process embodies the differing rules of fair play, which through the years, have becoine associated with differing types of proceedings." The proposals there rejected, we are told, "would inake a shambles of the investigation and stifle the ... gathering of facts." "[T]he investigative process could be completely disrupted. ... Fact-finding agencies ... would be diverted from their legitimate duties and would be plagued by the injection of collateral issues that would make the investigation interminable." ${ }^{\text {"7x }}$ Should reformers disregard those prestigious predictions? Or is it possible that the Court's inquiry in this single case may have greater effect on the whole course of investigatory reform than will a vigorous decade of scholarly research and writing?

The process of prescribing due process thus may even dominate reform. Efforts to improve its effectiveness could be widely rewarding indeed.

637,642 (1959). I now believe that I was mistaken, assuming that (1) we do not overly stress the word "regularly," and (2) administrative law includes the whole sweep of government and not inerely those proceedings that are the focus of inost law practice before agencies.

70 For a suggestion that officials sometimes are afraid to recognize more rights than due process demands see Rourke, Law Enforcement Through Publicity, 24 U. CEr. I. REv. 225, 253 n.108 (1957).

71363 U.S. at $442-44$. 